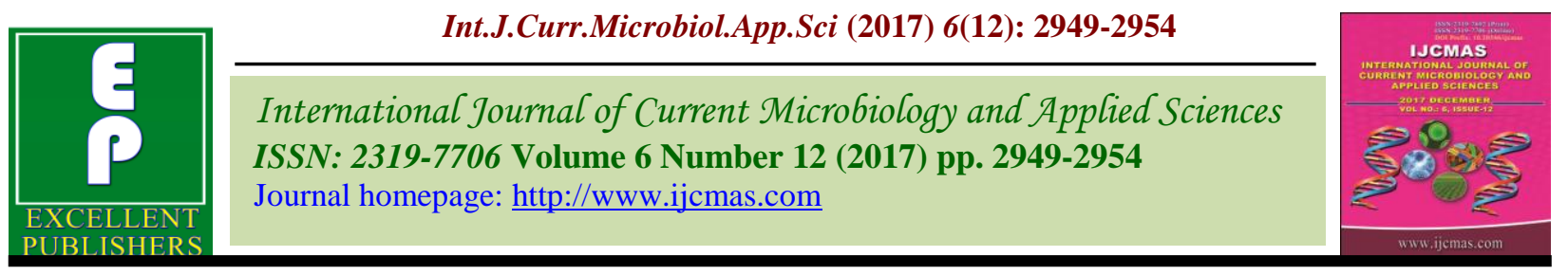

Original Research Article

https://doi.org/10.20546/ijcmas.2017.612.343

\title{
Effect of Nutrient Concentration on Vegetative Growth of Strawberry (Fragaria $\mathrm{x}$ ananassa)
}

\author{
Vikas, Arun Kumar, Anjil Kumar", Anshu Singh, Rajesh Saini, \\ Jaihoon Rafie and Vijay Kumar
}

Department of Horticulture, School of Agriculture, Lovely Professional University, Phagwara 144401, Punjab, India

School of Agriculture, Roorkee college of Engineering, Roorkee, 247667, Uttarakhand, India

*Corresponding author

\begin{tabular}{|c|c|}
\hline & A B S T R A C T \\
\hline & \multirow{4}{*}{$\begin{array}{l}\text { An experiment on effect of nutrient concentration on vegetative growth of } \\
\text { Strawberry (Fragaria x ananassa) was carried out during winter season of } \\
\text { the year 2016-2017 at Agriculture research farm, Department of Soil } \\
\text { Science, Lovely Professional University. This trial was operated based on a } \\
\text { Randomized Complete Block Design (RCBD) with nine treatments } \\
\text { including different ratios of farmyard manure, vermicompost and } \\
\text { recommended dose of fertilizer. The measured traits included Plant height } \\
(\mathrm{cm}) \text {, plant girth }(\mathrm{mm}) \text {, number of leaves/plant and Leaf area }\left(\mathrm{cm}^{2}\right) \text {, The } \\
\text { results revealed that T9 significantly increase growth attributing characters } \\
\text { like plant height }(6.9 \mathrm{~cm}) \text {, stem girth }(0.27 \mathrm{~mm}), \text { number of leaves/plant } \\
\text { (14.33) at 90days while maximum leaf area }\left(42.73 \mathrm{~cm}^{2}\right) \text { find at } 60 \text { days. }\end{array}$} \\
\hline $\begin{array}{l}\text { Chandler variety, } \\
\text { Vermicompost, } \\
\text { FYM and RCBD. }\end{array}$ & \\
\hline Article Info & \\
\hline $\begin{array}{l}\text { Accepted: } \\
21 \text { October } 2017 \\
\text { Available Online: } \\
10 \text { December } 2017\end{array}$ & \\
\hline
\end{tabular}

\section{Introduction}

Strawberry (Fragaria $x$ ananassa) is the popular soft fruit and mainly grows in subtropical and hills at elevation of 3000 meter. It cultivated mainly in protected structure and produce best quality and production of fruits. In sub-tropic region strawberry require $20^{\circ}$ $25^{\circ}$ temperature maximum in day time and minimum $7^{\circ}$ to $13^{\circ}$ temperature in night time. As compare to all berries it gives early fruits in short time. The strawberry rich in nutrients content like protein, $\mathrm{Ca}, \mathrm{P}$ and $\mathrm{K}$ with Vitamin-A, B1, B2, C and niacin. In last few decades the strawberry production and demand is increase in international market. The U.S.A is the largest producer of strawberry in the world. About 28\% world production of strawberry is given by U.S.A. as per the food and agriculture organization of united nation. And Spain is produced 8\% followed by the Russia, Korea, Japan and Poland. In India, strawberry is cultivated in hilly area like Himachal Pradesh, Uttaranchal, parts of Uttar Pradesh and Kashmir valley. But now a day it is also cultivated in north plain zone of India like Punjab, Haryana, Delhi and some part of Rajasthan. According 
to national horticulture board of India the production of strawberry in 2014-15 is $8000 \mathrm{MT}$ and under 2015-16 it is $5000 \mathrm{MT}$.

\section{Materials and Methods}

\section{Location of research}

It is carried out at Experimental Farm of School of Agriculture, Lovely Professional University, Phagwara, Punjab. The experiment shall be laid out on pot with three replications. The package of practices for raising the crop shall be followed as per latest PAU guidelines and check the Nitrogen, Phosphorus, Potassium and organic carbon of soil.

\section{Experimental details}

Period of work: Mid November to march 2017

Treatments: 9

Replications: 3

Total number of pots: $9 \times 3=27$

Design: RCBD on pots

Variety: Chandler

Seed rate: seedling plants

\section{Observation details}

For the determination of the plants growth selected various parameters viz., Plant height (cm), plant girth (mm), number of leaves/plant and Leaf area $\left(\mathrm{cm}^{2}\right)$.

\section{Statistical analysis}

The data collected during the course of investigation were subjected to statistical analysis by adopting appropriate method of analysis of variance as described by Fisher. The critical difference for the treatment comparison was worked out, wherever the SPSS 16 is used to analysis the data.

\section{Results and Discussion}

Plant height in different pot is observed at different days like 15 days, 30 days, 45 days, 60 days, 75 days and 90 days. And the variation is observed in different treatments in the plant height at different time period. In between the 15 days observation the plant height increase $29.62 \%$. In 30 days observation shows that $33.03 \%$ increase in between all treatments and according to this at 45 days data shows that the $30.30 \%$ increase in plant height; however the variation in treatment $\mathrm{T}_{8}, \mathrm{~T}_{9}(50 \% \mathrm{RDF}+50 \% \mathrm{FYM}, 25 \%$ $\mathrm{RDF}+75 \% \mathrm{FYM}$ ) are from $3.80-5.40 \mathrm{~cm}$ and 4.06-5.93 cm respectively (Table 1 ).

And it also depends on the different condition of the growing strawberry in poly house (Tripathi et al., 2015). In plant height at 30 days observation shows the $10.62 \%$ increase at 15 days; however the variation in treatments from $4.06-5.93 \mathrm{~cm}$ and $\mathrm{T}_{9}(25 \%$ $\mathrm{RDF}+75 \%$ FYM) shows the best plant height. Due to the application FYM and vermicompost, fertilizer increase the yield and growth $37 \%$ and also increase the activity of the microorganism due to this it effect on the uptake of water is more (Arancon et al., 2006).

But in these experiment the FYM and RDF (Recommended dose of fertilizer) shows the best plant height. Phosphorus with the organic manure increases the water retention capacity of soil it leads to the more plant height (Arancon et al., 2006). At 45 days observation shows that $13.17 \%$ increase as compared to the 30 days; however the variation from 4.76 to $6.83 \mathrm{~cm}$ and the $\mathrm{T}_{9}$ $(25 \% \mathrm{RDF}+75 \% \mathrm{FYM})$ shows the best impact on plant height. And after the vegetative growth of plant, the plant height was not increase. The plant height after the 45 days is not increase due to the stop of cell division after flowering (Morgan et al., 2006). 
Table. 1 The effect of nutrient concentration on strawberry plant height (cm) at 15, 30, 45, 60, 75 and 90 days. The mean follows by different letters are significant different at $\mathrm{p}<0.05$, according to DMRT (Duncan's Range Test) for separation of means

\begin{tabular}{lllllll}
\hline T & PH 15 Days & PH 30 Days & PH 45Days & PH 60Days & PH 75Days & PH 90Days \\
\hline T1 & $4.36 \mathrm{ab} \pm 0.42$ & $4.56 \mathrm{ab} \pm 0.41$ & $5.13 \mathrm{~cd} \pm 0.37$ & $5.16 \mathrm{bc} \pm 0.40$ & $5.16 \mathrm{~cd} \pm 0.40$ & $5.16 \mathrm{~cd} \pm 0.40$ \\
T2 & $5.16 \mathrm{ab} \pm 0.27$ & $5.26 \mathrm{ab} \pm 0.27$ & $5.60 \mathrm{bcd} \pm 0.25$ & $5.73 \mathrm{abc} \pm 0.24$ & $5.73 \mathrm{bcd} \pm 0.26$ & $5.73 \mathrm{bcd} \pm 0.26$ \\
T3 & $4.83 \mathrm{ab} \pm 0.63$ & $4.93 \mathrm{ab} \pm 0.57$ & $5.26 \mathrm{bcd} \pm 0.52$ & $5.33 \mathrm{bc} \pm 0.46$ & $5.33 \mathrm{~cd} \pm 0.46$ & $5.33 \mathrm{~cd} \pm 0.46$ \\
T4 & $3.80 \mathrm{~b} \pm 0.33$ & $4.06 \mathrm{~b} \pm 0.40$ & $4.76 \mathrm{~d} \pm 0.35$ & $4.96 \mathrm{c} \pm 0.35$ & $4.96 \mathrm{~d} \pm 0.35$ & $4.96 \mathrm{~d} \pm 0.35$ \\
T5 & $5.13 \mathrm{ab} \pm 0.73$ & $5.30 \mathrm{ab} \pm 0.72$ & $5.86 \mathrm{abcd} \pm 0.61$ & $5.93 \mathrm{abc} \pm 0.61$ & $5.93 \mathrm{abcd} \pm 0.61$ & $5.93 \mathrm{abcd} \pm 0.6$ \\
T6 & $5.13 \mathrm{ab} \pm 0.24$ & $5.30 \mathrm{ab} \pm 0.30$ & $5.73 \mathrm{abcd} \pm 0.31$ & $5.93 \mathrm{abc} \pm 0.31$ & $5.93 \mathrm{abcd} \pm 0.31$ & $5.93 \mathrm{abcd} \pm 0.31$ \\
T7 & $4.83 \mathrm{ab} \pm 0.24$ & $5.16 \mathrm{ab} \pm 0.14$ & $6.06 \mathrm{abc} \pm 0.14$ & $6.3 \mathrm{ab} \pm 0.08$ & $6.33 \mathrm{abc} \pm 0.08$ & $6.33 \mathrm{abc} \pm 0.08$ \\
T8 & $5.40 \mathrm{a} \pm 0.34$ & $5.66 \mathrm{a} \pm 0.31$ & $6.46 \mathrm{ab} \pm 0.23$ & $6.56 \mathrm{a} \pm 0.27$ & $6.56 \mathrm{ab} \pm 0.21$ & $6.56 \mathrm{ab} \pm 0.21$ \\
T9 & $5.30 \mathrm{ab} \pm 0.51$ & $5.93 \mathrm{a} \pm 0.49$ & $6.83 \mathrm{a} \pm 0.20$ & $6.90 \mathrm{a} \pm 0.23$ & $6.90 \mathrm{a} \pm 0.23$ & $6.90 \mathrm{a} \pm 0.23$ \\
\hline
\end{tabular}

$\mathrm{T}=$ Treatment, $\mathrm{PH}=$ Plant Height

Table.2 Data on the effect of nutrient concentration on strawberry stem girth ( $\mathrm{mm})$ at 15, 30, 45, 60, 75 and 90 days. The mean followed by different letters are significant different at $\mathrm{p}<0.05$, according to DMRT (Duncan's Range Test) for separation of means

\begin{tabular}{lllllll}
\hline T & SG 15 Days & SG 30Days & SG 45Days & SG 60Days & SG 75Days & SG 90Days \\
\hline T1 & $0.14 \mathrm{a} \pm 0.01$ & $0.17 \mathrm{a} \pm 0.02$ & $0.17 \mathrm{a} \mathrm{b} \pm 0.01$ & $0.19 \mathrm{a} \pm 0.03$ & $0.21 \mathrm{ab} \pm 0.02$ & $0.23 \mathrm{abc} \pm 0.02$ \\
T2 & $0.14 \mathrm{a} \pm 0.01$ & $0.15 \mathrm{a} \pm 0.01$ & $0.17 \mathrm{a} \mathrm{b} \pm 0.01$ & $0.19 \mathrm{a} \pm 0.01$ & $0.20 \mathrm{a} \mathrm{b} \pm 0.01$ & $0.23 \mathrm{abc} \pm 0.01$ \\
T3 & $0.13 \mathrm{a} \pm 0.01$ & $0.14 \mathrm{a} \pm 0.01$ & $0.15 \mathrm{a} \mathrm{b} \pm 0.01$ & $0.19 \mathrm{a} \pm 0.01$ & $0.21 \mathrm{~b} \pm 0.01$ & $0.22 \mathrm{bc} \pm 0.01$ \\
T4 & $0.13 \mathrm{a} \pm 0.02$ & $0.15 \mathrm{a} \pm 0.02$ & $0.16 \mathrm{a} \mathrm{b} \pm 0.01$ & $0.18 \mathrm{a} \pm 0.02$ & $0.19 \mathrm{~b} \pm 0.02$ & $0.21 \mathrm{c} \pm 0.01$ \\
T5 & $0.12 \mathrm{a} \pm 0.01$ & $0.14 \mathrm{a} \pm 0.01$ & $0.15 \mathrm{a} \mathrm{b} \pm 0.01$ & $0.17 \mathrm{a} \pm 0.01$ & $0.19 \mathrm{~b} \pm 0.01$ & $0.21 \mathrm{c} \pm 0.01$ \\
T6 & $0.11 \mathrm{a} \pm 0.01$ & $0.13 \mathrm{a} \pm 0.01$ & $0.14 \mathrm{~b} \pm 0.01$ & $0.15 \mathrm{a} \pm 0.01$ & $0.19 \mathrm{~b} \pm 0.01$ & $0.21 \mathrm{c} \pm 0.01$ \\
T7 & $0.14 \mathrm{a} \pm 0.01$ & $0.16 \mathrm{a} \pm 0.01$ & $0.17 \mathrm{a} \mathrm{b} \pm 0.01$ & $0.19 \mathrm{a} \pm 0.01$ & $0.21 \mathrm{ab} \pm 0.01$ & $0.23 \mathrm{abc} \pm 0.01$ \\
T8 & $0.18 \mathrm{a} \pm 0.02$ & $0.17 \mathrm{a} \pm 0.02$ & $0.18 \mathrm{a} \mathrm{b} \pm 0.03$ & $0.20 \mathrm{a} \pm 0.03$ & $0.22 \mathrm{a} \mathrm{b} \pm 0.02$ & $0.26 \mathrm{a} \pm 0.01$ \\
T9 & $0.17 \mathrm{a} \pm 0.03$ & $0.19 \mathrm{a} \pm 0.02$ & $0.20 \mathrm{a} \pm 0.02$ & $0.21 \mathrm{a} \pm 0.02$ & $0.25 \mathrm{a} \pm 0.01$ & $0.27 \mathrm{a} \pm 0.02$ \\
\hline
\end{tabular}

$\mathrm{T}=$ Treatment, $\mathrm{SG}=$ Stem Girth 
Table.3 Data on the effect of nutrient concentration on strawberry number of leaves/Plant at 15, 30, 45, 60, 75 and 90 days. The mean followed by different letters are significant different at $\mathrm{p}<0.05$, according to DMRT (Duncan's Range Test) for separation of means

\begin{tabular}{|c|c|c|c|c|c|c|}
\hline $\mathbf{T}$ & LP15Days & LP 30Days & LP 45Days & LP 60Days & LP 75Days & LP 90Days \\
\hline T1 & $3.33 a \pm 0.88$ & $8.00 \mathrm{a} \pm 0.00$ & $9.66 a \pm 0.33$ & $10.00 \mathrm{ab} \pm 0.00$ & $12.00 b \pm 1.15$ & $12.00 \mathrm{~b} \pm 1.15$ \\
\hline $\mathbf{T 2}$ & $4.00 \mathrm{a} \pm 1$ & $6.00 \mathrm{a} \pm 0.57$ & $7.66 \mathrm{ab} \pm 0.33$ & $9.33 b \pm 0.66$ & $10.66 b \pm 0.60$ & $10.66 \mathrm{~b} \pm 0.60$ \\
\hline T3 & $4.00 \mathrm{a} \pm 1$ & $5.66 \mathrm{a} \pm 1.2$ & $7.00 \mathrm{~b} \pm 0.57$ & $9.00 \mathrm{~b} \pm 0.57$ & $12.00 \mathrm{ab} \pm 0.77$ & $12.00 \mathrm{ab} \pm 0.77$ \\
\hline T4 & $3.33 a \pm 0.3$ & $6.33 a \pm 0.33$ & $8.33 \mathrm{ab} \pm 0.33$ & $10.66 \mathrm{ab} \pm 0.66$ & $12.33 \mathrm{ab} \pm 0.33$ & $12.33 \mathrm{ab} \pm 0.33$ \\
\hline T5 & $5.33 a \pm 1.4$ & $6.66 a \pm 1.20$ & $8.00 \mathrm{ab} \pm 1.0$ & $10.33 \mathrm{ab} \pm 0.88$ & $11.66 \mathrm{ab} \pm 1.2$ & $11.66 \mathrm{ab} \pm 1.2$ \\
\hline T6 & $4.66 a \pm 0.88$ & $7.00 \mathrm{a} \pm 1.00$ & $8.00 \mathrm{ab} \pm 0.57$ & $10.00 \mathrm{ab} \pm 0.00$ & $10.66 \mathrm{~b} \pm 0.66$ & $10.66 b \pm 0.66$ \\
\hline T7 & $3.33 \mathrm{a} \pm 0.88$ & $5.66 a \pm 0.66$ & $8.00 \mathrm{ab} \pm 0.00$ & $11.33 \mathrm{ab} \pm 0.66$ & $13.00 \mathrm{ab} \pm 0.57$ & $13.00 \mathrm{ab} \pm 0.57$ \\
\hline T8 & $5.66 \mathrm{a} \pm 1.4$ & $6.00 \mathrm{a} \pm 1.15$ & $8.00 \mathrm{ab} \pm 1.15$ & $11.66 a b \pm 1.85$ & $12.66 a b \pm 1.33$ & $12.66 \mathrm{ab} \pm 1.33$ \\
\hline T9 & $4.00 \mathrm{a} \pm 1$ & $5.66 a \pm 0.66$ & $8.00 \mathrm{ab} \pm 0.57$ & $12.66 a \pm 0.66$ & $14.33 a \pm 0.33$ & $14.33 a \pm 0.33$ \\
\hline
\end{tabular}

$\mathrm{T}=$ Treatment, $\mathrm{LP}=$ Leaf/plant

Table.4 Data on the effect of nutrient concentration on strawberry leaf area $\left(\mathrm{cm}^{2}\right)$ at $15,30,45$, 60,75 and 90 days. The mean followed by different letters are significant different at $\mathrm{p}<0.05$, according to DMRT (Duncan's Range Test) for separation of means

\begin{tabular}{|c|c|c|c|c|c|c|}
\hline $\mathbf{T}$ & LA 15 Days & LA 30Days & LA 45 Days & LA 60 Days & LA 75Days & LA 90 Days \\
\hline T1 & $11.13 b \pm 1.67$ & $18.00 \mathrm{ab} \pm 3.05$ & $13.10 \mathrm{a} \pm 2.82$ & $15.80 \mathrm{~b} \pm 3.36$ & $18.80 \mathrm{ab} \pm 6.32$ & $12.73 \mathrm{~cd} \pm 4.13$ \\
\hline $\mathbf{T} 2$ & $17.66 \mathrm{ab} \pm 0.88$ & $19.33 \mathrm{ab} \pm 4.33$ & $13.70 \mathrm{a} \pm 4.27$ & $18.80 \mathrm{~b} \pm 9.61$ & $13.70 b \pm 1.93$ & $11.43 \mathrm{~d} \pm 1.37$ \\
\hline T3 & $21.20 \mathrm{ab} \pm 3.74$ & $15.37 b \pm 3.90$ & $14.40 \mathrm{a} \pm 3.30$ & $16.83 b \pm 1.37$ & $19.33 b \pm 6.56$ & $14.46 \mathrm{bcd} \pm 4.82$ \\
\hline T4 & $13.23 b \pm 3.01$ & $28.70 \mathrm{a} \pm 0.90$ & $27.76 \mathrm{a} \pm 4.73$ & $14.96 \mathrm{~b} \pm 2.28$ & $14.70 \mathrm{~b} \pm 2.30$ & $10.37 \mathrm{~d} \pm 0.87$ \\
\hline T5 & $23.50 \mathrm{ab} \pm 5.23$ & $13.86 \mathrm{~b} \pm 2.54$ & $16.75 a \pm 1.75$ & $17.20 \mathrm{~b} \pm 4.61$ & $15.40 \mathrm{~b} \pm 3.11$ & $12.70 \mathrm{~cd} \pm 0.30$ \\
\hline T6 & $19.60 a b \pm 5.16$ & $20.13 a b \pm 0.46$ & $29.36 a \pm 6.71$ & $24.20 b \pm 2.34$ & $14.40 \mathrm{~b} \pm 3.21$ & $25.33 \mathrm{abc} \pm 7.42$ \\
\hline T7 & $29.00 \mathrm{a} \pm 7.23$ & $24.16 \mathrm{ab} \pm 4.84$ & $36.33 a \pm 3.71$ & $30.40 \mathrm{ab} \pm 8.33$ & $21.66 \mathrm{~b} \pm 5.23$ & $18.33 \mathrm{abcd} \pm 1.32$ \\
\hline T8 & $22.63 a b \pm 2.36$ & $19.10 \mathrm{ab} \pm 3.80$ & $27.70 \mathrm{a} \pm 7.72$ & $19.53 b \pm 3.01$ & $23.00 \mathrm{ab} \pm 4.58$ & $29.33 a \pm 5.36$ \\
\hline T9 & $22.76 a b \pm 2.36$ & $21.50 \mathrm{ab} \pm 3.37$ & $28.86 a \pm 4.96$ & $42.73 a \pm 2.96$ & $31.03 \mathrm{a} \pm 3.61$ & $26.40 \mathrm{ab} \pm 2.66$ \\
\hline
\end{tabular}

$\mathrm{T}=$ Treatment, LA=Leaf Area 


\section{Details of Treatment}

\begin{tabular}{|l|}
\hline $\mathrm{T}_{1}=$ Control \\
\hline $\mathrm{T}_{2}=100 \%$ Recommended dose of fertilizer $(\mathrm{RDF})$ \\
\hline $\mathrm{T}_{3}=75 \% \mathrm{RDF}+25 \%$ Vermicompost \\
\hline $\mathrm{T}_{4}=50 \% \mathrm{RDF}+50 \%$ Vermicompost \\
\hline $\mathrm{T}_{5}=25 \% \mathrm{RDF}+75 \%$ Vermicompost \\
\hline $\mathrm{T}_{6}=100 \%$ Vermicompost \\
\hline $\mathrm{T}_{7}=100 \%$ Farm yard manure $(\mathrm{FYM})$ \\
\hline $\mathrm{T}_{8}=50 \% \mathrm{RDF}+50 \%$ FYM \\
\hline $\mathrm{T}_{9}=25 \% \mathrm{RDF}+75 \%$ FYM \\
\hline
\end{tabular}

In between the treatment at 45 days, the stem girth is increase 30\%; At 75 days stem girth increase 24\%; At 90 days, stem girth increase $22.22 \%$. At 45 days stem girth observation shows that the $5 \%$ increase as compared to the 30 days; however variation is from 0.14$0.20 \mathrm{~mm}$ and $\mathrm{T}_{9}(25 \% \mathrm{RDF}+75 \% \mathrm{FYM})$ shows the best impact on stem girth. At 75 days the stem girth observation $16 \%$ increase as compared to the 60 days; however the variation is from $0.19-0.25 \mathrm{~mm}$ and $\mathrm{T}_{9}(25 \% \mathrm{RDF}+75 \% \mathrm{FYM})$ shows the best impact on the stem girth. At 90 days stem girth observation shows that the $7.40 \%$ increase as compared to the 75 days observation; however the variation in treatment are from $0.21-0.27 \mathrm{~mm}$ and $\mathrm{T}_{9}$ $(25 \% \mathrm{RDF}+75 \% \mathrm{FYM})$ shows the best impact on stem girth. This impact is may be due the microorganism and FYM. (Arancon et al., 2006) tell about the $37 \%$ increase in the shoot biomass due to organic fertilizer (Table 2).

Number of leaves/plant increase till the flowering period because the division of cell is stop after flowering (Morgan et al., 2006). In between the 45 days observation of all treatment the leaf/plant increase $27.53 \%$; at 60 days shows that $28.90 \%$ increase in leaf/ plant. At 45 days observation shows that the $19.14 \%$ increase of leaf/plant as compared to the 30 days; however the variation in treatment is from 7-9.66 leafs and $T_{1}$ control shows best impact on leaf/plant. At 60 days observation shows that the $22.22 \%$ increase as compared to the 45 days; however the variation in treatment are from 9-12.66 leafs and $\mathrm{T}_{9}(25 \% \mathrm{RDF}+75 \%$ FYM $)$ shows best impact on the leaf/plant (Table 3). At 75 days results shows that $16.66 \%$ increase as compared to the 90 days; however the variation in treatment are from 10.66-14.33 leafs and $\mathrm{T}_{9}(25 \% \mathrm{RDF}+75 \% \mathrm{FYM})$ shows that best impact on leaf/plant. But the vermicompost change the biological activity (Cristina and Jorge et al., 2011) and the availability of the different nutrient change in the soil due to the vermicompost and if increase the number of leaves per plant (Mamta et al., 2012). At 15 days, leaf area increase $61.62 \%$ in between all treatment; $51.70 \%$ increase in 30 days; $63.94 \%$ increase in 60days; $64.98 \%$ increase in 75 days; and $27.13 \%$ increase in 90days.At 45 days leaf area observation shows that $53.90 \%$ increase as compared to the 30 days; The variation in treatment are from $13.86-28.70 \mathrm{~cm}^{2}$ and $\mathrm{T}_{4}$ $(50 \% \mathrm{RDF}+50 \%$ vermicompost) shows the best impact on the leaf area. Due to the application of vermicompost helpful for increase the leaf area (10.1- 18.9\%) (Papadopoulos el al., 1987). At 60 days the result shows the $32.45 \%$ as compare to 45 days; however the variation in treatment are from 14.96-42.76 $\mathrm{cm}^{2}$ and $\mathrm{T}_{9}$ (25\%RDF + $75 \% \mathrm{FYM}$ ) shows best impact on leaf area. At 75 days leaf area observation shows the $15.95 \%$ increase as compared to the 60 days; 
the variation in treatment are in between 13.70-18.80 $\mathrm{cm}^{2}$ and $\mathrm{T}_{1}$ (control) shows the best impact on the leaf area (Table 4). In soil sample the phosphorus is more and the fruits plant is more uptakes of the phosphorus nutrient it impact on the leaf area. At 90days leaf area of plants show that the $21.58 \%$ increase as compared to the 75 days; however the variation in treatment are from 10.37$29.33 \mathrm{~cm}^{2}$ and $\mathrm{T}_{8}(50 \% \mathrm{RDF}+50 \% \mathrm{FYM})$ gives good result on leaf area. But the vermicompost increases the macro and micro pore in soil which effect on air water retention it increase the plant growth (Nagavallemma et al., 2004).

\section{Acknowledgement}

I am extremely grateful to my advisor and Department of Soil Science, LPU, Punjab for providing all facilities related to my research work.

\section{References}

Cristina, L. et al.,2011. "The use of vermicompost in sustainable agriculture: impact plant growth and soil fertility" Nova science publisher PP 2-16.

Mamta, K. et al., 2012. "Effect of Vermicompost on the growth of Brinjal plant under field" Journal of new biological Report PP 25-28.

Morgan, et al.,2006. "A technical guide to the hydroponic production of strawberry" pages 43-69.

Nagavallemma, K.P. et al.,2004. "Vermicomposting Recycling Waste into valuable Organic fertilizer" PP 120. International Crops Research Institute for the semi-Arid Tropics.

Arancon, N.Q. et al.,2006. "Influences of vermicomposts on field strawberries: Part 2. Effects on soil microbiological and chemical properties "Bioresource TechnologyPages 831-840.

Papadopoulos, et al.,1987. "Nitrogen fertigation of greenhouse grown strawberry "Fertilizer PP 269-276.

Tripathi, V.K., Kumar, S. and Gupta, A.K. 2015. Influence of Azotobacter and vermicompost on growth, flowering, yield and quality of strawberry cv. Chandler. Indian J. Hort. 72(2): 201205.

\section{How to cite this article:}

Vikas, Arun Kumar, Anjil Kumar, Anshu Singh, Rajesh Saini, Jaihoon Rafie and Vijay Kumar. 2017. Effect of Nutrient Concentration on Vegetative Growth of Strawberry (Fragaria x ananassa). Int.J.Curr.Microbiol.App.Sci. 6(12): 2949-2954.

doi: https://doi.org/10.20546/ijcmas.2017.612.343 